\title{
Mechanical Deformation in Patients with Systemic Arterial Hypertension
}

Leonel Avendaño-Pérez', María Elena Soto ${ }^{2}$, Nydia Ávila-Vanzziniं ${ }^{3}$, Erick Alexanderson-Rosas ${ }^{4}$ and Nilda Espinola-Zavaleta $^{1,4 *}$

${ }^{1}$ Laboratory of Non-invasive Hemodynamics, National Institute of Cardiology "Ignacio Chávez", Mexico

2Department Immunology, National Institute of Cardiology "Ignacio Chavez", Mexico

${ }^{3}$ Department of Out-patients Clinic, National Institute of Cardiology "Ignacio Chávez", Mexico

${ }^{4}$ Department of Nuclear Medicine, National Institute of Cardiology "Ignacio Chavez", Mexico

\section{Abstract}

Background: Systemic arterial hypertension represents the mayor risk factor for several cardiovascular diseases. In a large number of patients it affects the left ventricle by a compensating hypertrophy and posteriorly when this mechanism is insufficient, it leads to heart failure and therefore the patient requires regular echocardiographic monitoring. Subclinical dysfunction of the left ventricle exists even in asymptomatic hypertensive patients with preserved left ventricular ejection fraction.

Objectives: The main aim of our study was focused in the assessment of left ventricular mechanical deformation in 20 patients with systemic arterial hypertension and 21 healthy controls.

Results: A total of 41 subjects were studied, 22 women and 19 men. The hypertensive group consisted of 20 patients and the healthy control group of 21 subjects. The echocardiographic findings that had significative differences between hypertensive patients and healthy controls were left ventricle mass index, E/A ratio, E/e' ratio and systolic pulmonary arterial pressure. In patients with hypertension, the radial deformation had a significative reduction, $p=0.002$, but the longitudinal deformation was statistically decreased $(p=0.008)$, only in the subgroup of hypertensive patients with left ventricular hypertrophy.

Conclusion: The patients with systemic hypertension require a close follow-up in order to identify the most accurate echocardiographic parameter for diagnosis of subclinical dysfunction. In our study, the global radial deformation was significatively diminished in the hypertensive patients and the global longitudinal deformation was decreased only in the subgroup of hypertensive patients with left ventricular hypertrophy.

Keywords: Systemic hypertension; Mechanical deformation; Speckle tracking

\section{Introduction}

Hypertension is one of the most important healthy problems, and the prevalence is of around $20 \%$ of the population (variable in different regions of the world), and the hypertension is one of the most important risk factor for cardiovascular diseases, which are the leading causes of death in developed countries [1,2]. Both elevation of systolic pressure and diastolic blood pressure shows a continuous relationship with cardiovascular risk of stroke, coronary heart disease, heart failure, renal failure and peripheral arterial disease [3].

Hypertension can cause left ventricular hypertrophy and hyperplasia of the smooth muscle cells and increased production of collagen and elastin tissue. Hypertension represents an increase in cardiac afterload and the compensatory mechanism of is the development of left ventricular concentric hypertrophy. However, unlike hypertrophy which occurs in athletes, the hypertrophy in hypertensive patients occurs with an increase of collagen tissue production, a fact that in the long term leads to left ventricular diastolic dysfunction and secondarily atrial dysfunction by increasing filling pressures predisposing to atrial fibrillation, and in advanced stages systolic dysfunction with dilatation of the cavity and the appearance of heart failure and ventricular arrhythmias [4]. In addition, hypertrophy of the ventricular wall increases the oxygen myocardial demands, which together with the increase incidence of coronary lesions favour myocardial ischemia [5].

Several studies have found heterogeneous systolic alterations of the left ventricle (in the longitudinal, radial, and circumferential directions) in diverse clinical settings such as diabetes, hypertension, left ventricle hypertrophy, coronary artery disease, and heart failure $[4,6]$.
The main aim of our study was focused in the assessment of left ventricular mechanical deformation in 20 patients with systemic arterial hypertension and 21 healthy controls to establish the differences in the left ventricular mechanical deformation.

\section{Materials and Methods}

Between March 2016 and February 2017, a comparative, observational, prospective, descriptive and analytical study was carried out in 41 subjects. The patients were evaluated consecutively in the Out-patients Clinic, National Institute of Cardiology "Ignacio Chávez". Twenty patients had systemic hypertension and 21 correspond to healthy controls. All participants signed the informed consent.

\section{Inclusion criteria}

Patients older than 18 years NYHA functional class I/II with a diagnosis of systemic hypertension who had not had any prior surgical or interventional procedure and also patients without valvular or myocardial lesion.

${ }^{*}$ Corresponding author: Dr. Nilda Espinola-Zavaleta, Laboratory of Non-invasive Hemodynamics, Department of Nuclear Medicine, National Institute of Cardiology Ignacio Chavez, Juan Badiano № 1, Colonia Sección XVI Tlalpan C. P. 14030 Ciudad de México, México, Tel: 6862696606; E-mail: niesza2001@hotmail.com

Received September 19, 2017; Accepted November 08, 2017; Published November 15, 2017

Citation: Avendaño-Pérez L, Soto ME, Vanzzini NÁ, Alexanderson-Rosas E Espinola-Zavaleta N (2017) Mechanical Deformation in Patients with Systemic Arterial Hypertension. J Hypertens (Los Angel) 6: 247. doi: 10.4172/21671095.1000247

Copyright: @ 2017 Avendaño-Pérez L, et al. This is an open-access article distributed under the terms of the Creative Commons Attribution License, which permits unrestricted use, distribution, and reproduction in any medium, provided the original author and source are credited. 
Citation: Avendaño-Pérez L, Soto ME, Vanzzini NÁ, Alexanderson-Rosas E, Espinola-Zavaleta N (2017) Mechanical Deformation in Patients with Systemic Arterial Hypertension. J Hypertens (Los Angel) 6: 247. doi: 10.4172/2167-1095.1000247

Page 2 of 4

\section{Exclusion criteria}

All patients with myocardial or valvular lesion or associated congenital heart disease, patients with secondary systemic hypertension, patients with poor acoustic window and patients with poor NYHA functional class. The control group had no clinical symptoms, and the electrocardiogram and echocardiogram were normal. All patients had a complete medical history, twelve-lead resting electrocardiogram, conventional transthoracic echocardiogram following current guidelines and longitudinal, circumferential and radial deformation by speckle tracking $[7,8]$.

\section{Echocardiographic study}

Conventional transthoracic echocardiographic studies were performed using commercially available equipment Vivid 9, X-clear (GE Vingmed Ultrasound, Horten, Noruega). Ventricular diameters were obtained in the end-diastole and in the end-systole in the parasternal long axis view, and the thickness of the interventricular septum and the posterior wall in end-diastole in the parasternal long axis view, according to the guidelines of the American Society of Echocardiography [7].

The diastolic function was determined with pulsed Doppler in the apical 4 chamber plane, placing the sample volume at the tip of the mitral valves to measure the $\mathrm{E}$ wave and $\mathrm{A}$ wave peak velocities and the E/A ratio (diastolic dysfunction was considered when E/A ratio $<0.8$ or $\geq 2$ ). The velocity of tissue septal wave $\left(e^{\prime}\right)$ was measured by tissue Doppler, placing the sample volume at the basal portion of the interventricular septum. When the E/e ratio $>14$, it was considered as an increase in the left ventricular filling pressures [7].

\section{Speckle tracking}

Three apical planes: four, three and two chambers, were used for determination of longitudinal deformation and for the radial and circumferential deformation the short axes at the level of the miral valve, papillary muscles and apical. The values of the global longitudinal deformation we took as normal were: $\geq-20 \%$, circumferential deformation $\geq-25 \%$ and radial deformation $\geq 40 \%$. The normal value of the twist is $9.9 \pm 4.1$ degrees and that of the rotation of $1.35 \% \mathrm{~cm} \pm$ $0.54[8,9]$ (Figure 1).

\section{Statistical Analysis}

Quantitative variables are presented as means \pm standard deviation. For comparison of groups and subgroups, when the distribution was normal or Gaussian, Student's t-test was used, otherwise the MannWhitney nonparametric test or sum of ranges was used. Categorical variables were compared using Fisher's exact test. All statistical analyses were performed with SPSS version 17.0 (SPSS Inc., Chicago, IL, USA). Findings were considered statistically significant if $\mathrm{p}$ was $\leq 0.05$.

\section{Results}

A total of 41 subjects were studied, 22 women (53.7\%) and 19 men (46.3\%), with an average of $43 \pm 18$ years. The demographic and clinical characteristics of the studied groups are shown in Table 1.

The echocardiographic findings are shown in Table 2. Statistically significant differences were found in Left atrial volume, inter-ventricular septum, posterior Wall thickness, left ventricular diastolic diameter, left ventricular relative wall thickness, left ventricle mass index, E/A ratio, $\mathrm{E} / \mathrm{e}^{\prime}$ ratio, systolic pulmonary artery pressure.

The values of longitudinal, radial, circumferential, rotation and

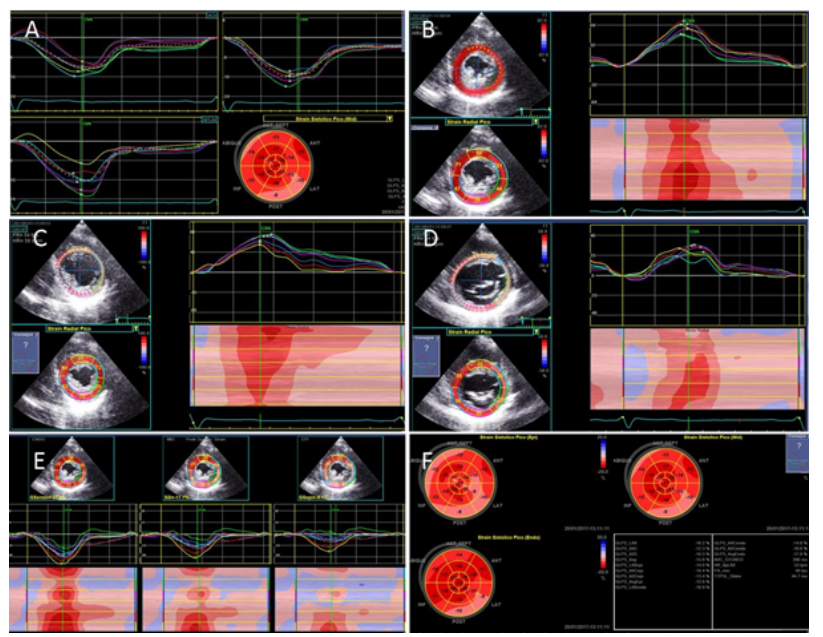

Figure 1: Left ventricle mechanical deformation in a patient with systemic hypertension.

\begin{tabular}{|c|c|c|c|c|}
\hline & Total $(\mathrm{N}=\mathbf{4 1})$ & SAH $(n=20)$ & Control $(n=21)$ & $p$ \\
\hline Age (years) & $43 \pm 18$ & $58 \pm 11$ & $28 \pm 8$ & 0.005 \\
\hline \multirow{2}{*}{ Gender } & + 22 & 우 14 & q 8 & \multirow{2}{*}{ - } \\
\hline & 319 & 6 & ๙13 & \\
\hline Weight (kg) & $73 \pm 13$ & $73 \pm 15$ & $73 \pm 10$ & NS \\
\hline Height (m) & $1.60 \pm 0.10$ & $1.56 \pm 0.07$ & $1.7 \pm 1.0$ & 0.005 \\
\hline $\begin{array}{l}\text { Body Mass Index (kg/ } \\
\left.\mathbf{m}^{2}\right)\end{array}$ & $27.5 \pm 5.2$ & $29.9 \pm 5.7$ & $25.2 \pm 3.6$ & 0.003 \\
\hline \multicolumn{5}{|l|}{ Ventricular geometry } \\
\hline Normal geometry & $18(44)$ & $2(10)$ & $16(72)$ & 0.001 \\
\hline Concentric remodeling & $17(42)$ & $12(60)$ & $5(24)$ & 0.001 \\
\hline Concentric hypertrophy & $6(14)$ & $6(30)$ & 0 & 0.001 \\
\hline \multicolumn{5}{|c|}{ SAH: Systemic Arterial Hypertension } \\
\hline
\end{tabular}

Table 1: Clinical and demographic parameters of the studied groups.

twist deformation are shown in Table 3. Significant changes were observed only in the radial deformation of the left ventricle in patients with systemic hypertension $(\mathrm{p}<0.002)$. Twist and rotation did not show statistical significance in any of the studied groups.

The global longitudinal deformation of the left ventricle was significantly decreased $(\mathrm{p}<0.008)$ in the subgroup of hypertensive patients with left ventricular hypertrophy.

\section{Discussion}

In our study we found that there is significant difference between the control group and hypertensive. In our study, age had a statistically significant difference, because essential systemic arterial hypertension is present in patients in the fourth decade of life. The influence of age on strain is still controversial, some studies described reduced strain with increasing age, and others found no correlation between strains and age [10-12].

The $76 \%$ of the controls had normal left ventricular geometry and only $24 \%$ had concentric remodeling. In contrast, almost all hypertensive patients had concentric remodeling $(60 \%)$ or concentric hypertrophy (30\%) and only 2 patients had normal left ventricular 
Citation: Avendaño-Pérez L, Soto ME, Vanzzini NÁ, Alexanderson-Rosas E, Espinola-Zavaleta N (2017) Mechanical Deformation in Patients with Systemic Arterial Hypertension. J Hypertens (Los Angel) 6: 247. doi: 10.4172/2167-1095.1000247

Page 3 of 4

\begin{tabular}{|c|c|c|c|c|}
\hline & $\begin{array}{c}\text { Total } \\
(\mathrm{N}=41)\end{array}$ & $\begin{array}{l}\text { SAH } \\
(n=20)\end{array}$ & $\begin{array}{c}\text { Control } \\
(n=21)\end{array}$ & $p$ \\
\hline Left atrial diameter $(\mathrm{mm})$ & $\begin{array}{c}35.3 \pm \\
4.9\end{array}$ & $\begin{array}{l}36.7 \pm \\
5.3\end{array}$ & $34 \pm 4.3$ & NS \\
\hline Left atrial volume $\left(\mathrm{ml} / \mathrm{m}^{2}\right)$ & $\begin{array}{c}26.8 \pm \\
9.6\end{array}$ & $34 \pm 7.8$ & $19.8 \pm 4.9$ & 0.005 \\
\hline Interventricular septum (mm) & $9.8 \pm 2.2$ & $11 \pm 2$ & $8.5 \pm 1.4$ & 0.005 \\
\hline Posterior Wall thickness (mm) & $9.6 \pm 2$ & $11 \pm 1.5$ & $8.2 \pm 1.5$ & 0.005 \\
\hline $\begin{array}{l}\text { Left ventricular diastolic diameter } \\
\qquad(\mathrm{mm})\end{array}$ & $42 \pm 4.7$ & $40 \pm 4.6$ & $44.7 \pm 3.9$ & 0.004 \\
\hline $\begin{array}{l}\text { Left ventricular systolic diameter } \\
\text { (mm) }\end{array}$ & $\begin{array}{c}26.5 \pm \\
4.4\end{array}$ & $\begin{array}{c}25.2 \pm \\
4.8\end{array}$ & $27.7 \pm 3.8$ & NS \\
\hline $\begin{array}{c}\text { Left ventricular relative wall } \\
\text { thickness }\end{array}$ & $\begin{array}{l}0.459 \pm \\
0.128\end{array}$ & $\begin{array}{c}0.552 \pm \\
0.101\end{array}$ & $\begin{array}{c}0.371 \pm \\
0.079\end{array}$ & 0.005 \\
\hline $\begin{array}{c}\text { Left ventricular ejection fraction } \\
(\%)\end{array}$ & $67 \pm 4$ & $68 \pm 5$ & $66 \pm 3$ & NS \\
\hline Left ventricle mass index $\left(\mathrm{gr} / \mathrm{m}^{2}\right)$ & $\begin{array}{l}74.6 \pm \\
24.6\end{array}$ & $\begin{array}{c}89.2 \pm \\
20.4\end{array}$ & $\begin{array}{c}60.7 \pm \\
20.1\end{array}$ & 0.005 \\
\hline E/A ratio & $\begin{array}{l}1.19 \pm \\
0.4\end{array}$ & $\begin{array}{l}0.897 \pm \\
0.279\end{array}$ & $\begin{array}{c}1.470 \pm \\
0.30\end{array}$ & 0.005 \\
\hline E/e' ratio & $\begin{array}{l}7.65 \pm \\
2.3\end{array}$ & $\begin{array}{l}9.27 \pm \\
2.14\end{array}$ & $\begin{array}{c}6.12 \pm \\
1.13\end{array}$ & 0.005 \\
\hline $\begin{array}{l}\text { Basal right ventricular diameter } \\
\qquad(\mathrm{mm})\end{array}$ & $\begin{array}{l}35.5 \pm \\
3.5\end{array}$ & $\begin{array}{c}35.25 \pm \\
3.7\end{array}$ & $\begin{array}{l}35.76 \pm \\
3.55\end{array}$ & NS \\
\hline $\begin{array}{l}\text { Tricuspid annular systolic } \\
\text { displacement (mm) }\end{array}$ & $\begin{array}{l}22.6 \pm \\
2.7\end{array}$ & $\begin{array}{c}22.35 \pm \\
2.8\end{array}$ & $23 \pm 2.8$ & NS \\
\hline $\begin{array}{l}\text { Systolic pulmonary artery } \\
\text { pressure }(\mathrm{mmHg})\end{array}$ & $\begin{array}{c}29.3 \pm \\
6.4\end{array}$ & $32.5 \pm 6$ & $\begin{array}{c}26.38 \pm \\
5.5\end{array}$ & 0.002 \\
\hline
\end{tabular}

$\mathrm{SAH}:$ Systemic Arterial Hypertension

Table 2: Echocardiographic parameters

\begin{tabular}{|c|c|c|c|c|}
\hline & $\begin{array}{c}\text { Total } \\
(\mathbf{N = 4 1 )}\end{array}$ & SAH (n=20) & $\begin{array}{c}\text { Control } \\
(\mathbf{n = 2 1 )}\end{array}$ & $\boldsymbol{p}$ \\
\hline Global radial strain (\%) & $44.2 \pm 11.9$ & $38.6 \pm 11.7$ & $49.54 \pm 9.6$ & 0.002 \\
\hline $\begin{array}{c}\text { Global circunferential strain } \\
(\%)\end{array}$ & $-18.5 \pm 3.8$ & $-18.5 \pm 4$ & $-18.6 \pm 3.7$ & NS \\
\hline $\begin{array}{c}\text { Global longitudinal strain } \\
(\%)\end{array}$ & $\begin{array}{c}-20.7 \pm \\
2.09\end{array}$ & $-20.47 \pm 2.3$ & $-20.97 \pm 1.8$ & NS \\
\hline Twist (\%) & $\begin{array}{c}16.52 \pm \\
8.08\end{array}$ & $17.2 \pm 9.2$ & $15.7 \pm 6.9$ & NS \\
\hline Torsion (\%)m) & $\begin{array}{c}2.251 \pm \\
1.08\end{array}$ & $2.38 \pm 1.28$ & $2.12 \pm 0.86$ & NS \\
\hline
\end{tabular}

NS: Not significant, SAH: Systemic Arterial Hypertension

Table 3: Left ventricular strain in control group and in patients with systemic hypertension

geometry. This change in the left ventricular geometry in hypertensive patients is due to the increase in afterload that is given by systemic hypertension itself $[1,4]$.

Our study shows, that the E/A mitral ratio was abnormal in hypertensive patients with impairment of left ventricular relaxation. Impairment of left ventricular filling and increased left ventricular mass index suggest phenotypic alterations at the myocyte level of the hypertensive heart $[13,14]$ different from physiologic hypertrophy as can be seen in athletes [15]. The E/e' ratio was significative different between groups, but its values indicate that the left ventricular filling pressures were normal.

In the analysis of left ventricular mechanics between the group of hypertensive and controls a significant reduction in the radial deformation was found. The longitudinal, circumferential and rotational mechanics did not show statistical significance. Unlike, other studies described that the first signs of left ventricular subclinical dysfunction

\begin{tabular}{|c|c|c|c|c|}
\hline & $\begin{array}{c}\text { Total } \\
(\mathbf{N = 2 0 )}\end{array}$ & $\begin{array}{c}\text { Concentric } \\
\text { hypertrophy (n=20) }\end{array}$ & $\begin{array}{c}\text { Normal } \\
\text { geometry (n=21) }\end{array}$ & $p$ \\
\hline $\begin{array}{c}\text { Global radial strain } \\
\text { (\%) }\end{array}$ & $\begin{array}{c}38.6 \pm \\
11.7\end{array}$ & $43.33 \pm 14.39$ & $40.41 \pm 24.67$ & NS \\
\hline $\begin{array}{c}\text { Global circunferential } \\
\text { strain (\%) }\end{array}$ & $\begin{array}{c}-18.5 \\
\pm 4\end{array}$ & $17.53 \pm 3.30$ & $19.98 \pm 6.05$ & NS \\
\hline $\begin{array}{c}\text { Global longitudinal } \\
\text { strain (\%) }\end{array}$ & $\begin{array}{c}-20.47 \pm \\
2.3\end{array}$ & $20.72 \pm 0.738$ & $22.40 \pm 0.141$ & 0.008 \\
\hline \multicolumn{4}{|c|}{ NS: Not significant } & \\
\hline
\end{tabular}

Table 4: Left ventricle strain in hypertensive patient's group with and without hypertrophy

is an increase of the radial deformation as a compensatory mechanism and that later there is a decrease of the radial, circumferential and longitudinal strain.

The mechanism of LV wall thickening in the radial direction is still unclear. LeGrice IJ et al. [16,17] have shown that myocardial fibers are grouped into lamina three to four cells thick that are interconnected by an extensive extracellular matrix and that longitudinal-radial shear of these sheets is likely to be an important mechanism underlying wall thickening.

In our study the longitudinal deformation showed a significant decrease in the subgroup of hypertensive patients with left ventricular hypertrophy in comparison to those without left ventricular hypertrophy (Table 4). In left ventricular hypertrophy, there is an increase in the amount of collagen, with a corresponding increment in the width and continuity of fibrillar components of the extracellular matrix, which may disturb wall thickening [18]. This shows that these hypertensive patients with subclinical left ventricular dysfunction determined by a decrease of their global longitudinal deformation should be closely monitored and initiate protective measures to avoid the development of left ventricular failure.

\section{Conclusion}

In hypertensive patients the global radial deformation was significatively decreased and the global longitudinal deformation was decreased only in the hypertensive patients with left ventricular hypertrophy.

This speckle tracking gives the physician knowledge of subclinical left ventricular dysfunction in hypertensive patients and allows the establishment of guidelines for initiating treatment to prevent the development of heart failure.

\section{References}

1. Wolf-Maier K, Cooper RS, Banegas JR, Giampaoli S, Hans-Werner $\mathrm{H}$, et al. (2003) Hypertension prevalence and blood pressure levels in 6 European countries, Canada and the United States. JAMA 289: 2363-2369.

2. Rosas PM, Palomo PS, Borrayo SG, Madrid MA, Almeida GE, et al. (2016) Concensus on systemic arterial hypertension in México. Rev Med Inst Seguro Soc (Mexico) 54: 6-51

3. Chobanian AV, Bakis GI, Black HR, Cushman WC, Green LA, Izzo JL, et al (2003). The JNC 7 hypertension guidelines. JAMA 290: 33-58.

4. Tadic M, Cuspidi C, Majstorovic A, Kocijancic V, Celic V (2015) The relationship between left ventricular deformation and different geometric patterns according to the updated classification. J Hypertension 33: 1954-1961.

5. Gaasch WH, Zile MR (2011) Left ventricular structural remodeling in health and disease: with special emphasis on volume, mass, and geometry. J Am Coll Cardiol 58: 1733-1740.

6. Morris D, Otani K, Bekfani T, Takigiku K. Izumi C, et al. (2014) Multidirectional global left ventricular systolic function in normal subjects and patients with hypertension: Multicenter evaluation. J Am Soc Echocardiogr 27: 493-500. 
Citation: Avendaño-Pérez L, Soto ME, Vanzzini NÁ, Alexanderson-Rosas E, Espinola-Zavaleta N (2017) Mechanical Deformation in Patients with Systemic Arterial Hypertension. J Hypertens (Los Angel) 6: 247. doi: 10.4172/2167-1095.1000247

Page 4 of 4

7. Lang R, Badano L, Mor-Avi V, Afilalo J, Armstrong A, et al. (2017) Recommendations for cardiac chamber quantification by echocardiography in adults: An update from the american society of echocardiography and the european association of cardiovascular imaging. J Am Soc Echocardiogr 28:139.

8. Voigt JU, Pedrizzetti G, Lysyansky P, Marwick TH, Houle H, et al. (2015) Definitions for a common standard for 2D speckle tracking echocardiography: consensus document of the EACVI/ASE/industry task force to standardize deformation imaging. J Am Soc Echocardiogr 28: 183-193.

9. Kouzu H, Yuda S, Muranaka A, Doi T, Yamamoto H, et al. (2011) Left ventricular hypertrophy causes different changes in longitudinal, radial, and circumferential mechanics in patients with hypertension: A two-dimensional speckle tracking study. J Am Soc Echocardiogr 24: 192-199.

10. Dalen H, Thorstensen A, Aase SA, Ingul CB, Torp H, et al. (2010) Segmental and global longitudinal strain and strain rate based on echocardiography of 1266 healthy individuals: The HUNT study in Norway. Eur J Echocardiogr 11: 176-183.

11. Kuznetsova T, Herbots L, Richart T, D'hooge J, Thijs L, et al. (2008) Left ventricular strain and strain rate in a general population. Eur Heart J 29: 2014 2023.

12. Sun JP, Popovic ZB, Greenberg NL, Xu X, Asher CR, et al. (2004) Noninvasive quantification of regional myocardial function using Doppler-derived velocity, displacement, strain rate, and strain in healthy volunteers: effects of aging. $J$ Am Soc Echocardiogr 17: 132-138.

13. Lamb HJ, Singleton RR, van der Geest RJ, Pohost GM, de Roos A (1995) MR imaging of regional cardiac function: low-pass filtering of wall thickness curves. Magn Reson Med 34: 498-502.

14. Granger CB, Karimeddini MK, Smith V, Shapiro HR, Katz AM, et al. (1985) Rapid ventricular filling in left ventricular hypertrophy, I: physiologic hypertrophy. J Am Coll Cardiol 5: 862-868.

15. Pluim BM, Lamb HJ, Kayser HWM, Leujes F, Beijerbacht HP, et al. (1998) Functional and metabolic evaluation of the athlete's heart by magnetic resonance imaging and dobutamine stress magnetic resonance spectroscopy. Circulation 97: 666-672.

6. LeGrice IJ, Takayama Y, Covell JW (1995) Transverse shear along myocardia cleavage planes provides a mechanism for normal systolic wall thickening. Circ Res 77: 182-193.

17. LeGrice IJ, Smaill BH, Chai LZ, Edgar SG, Gavin JB, et al. (1995) Laminar structure of the heart ventricular myocyte arrangement and connective tissue architecture in the dog. Am J Physiol 269: H571- H582.

18. Aurigemma GP, Zile MR, Gaasch WH (2006) Contractile behavior of the left ventricle in diastolic heart failure: with emphasis on regional systolic function. Circulation 113: 296-304 